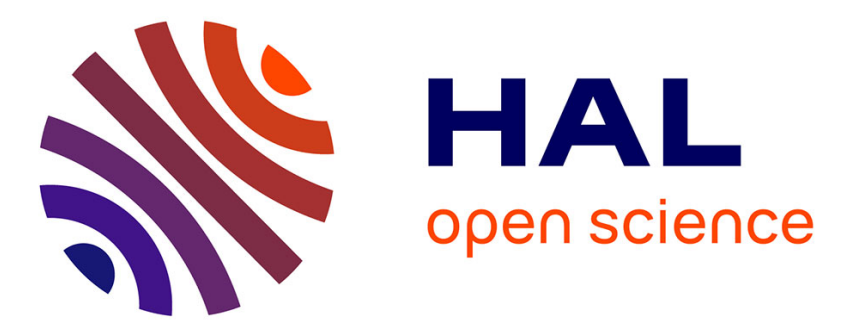

\title{
The management of the transition from hay- to pasture-based diets affects milk fatty acid kinetics
}

Coppa, Gorlier, Lonati, Martin, Enza Russo, Lombardi

\section{To cite this version:}

Coppa, Gorlier, Lonati, Martin, Enza Russo, et al.. The management of the transition from hayto pasture-based diets affects milk fatty acid kinetics. Dairy Science \& Technology, 2012, 92 (3), pp.279-295. 10.1007/s13594-012-0065-6 . hal-00930629

\section{HAL Id: hal-00930629 \\ https://hal.science/hal-00930629}

Submitted on 1 Jan 2012

HAL is a multi-disciplinary open access archive for the deposit and dissemination of scientific research documents, whether they are published or not. The documents may come from teaching and research institutions in France or abroad, or from public or private research centers.
L'archive ouverte pluridisciplinaire HAL, est destinée au dépôt et à la diffusion de documents scientifiques de niveau recherche, publiés ou non, émanant des établissements d'enseignement et de recherche français ou étrangers, des laboratoires publics ou privés.

$$
\text { Copyright }
$$




\title{
The management of the transition from hay- to pasture-based diets affects milk fatty acid kinetics
}

\author{
Mauro Coppa • Alessandra Gorlier • \\ Michele Lonati • Bruno Martin • \\ Enza Monica Russo • Giampiero Lombardi
}

Received: 22 November 2011 / Revised: 4 March 2012 / Accepted: 5 March 2012 /

Published online: 27 April 2012

C) INRA and Springer-Verlag, France 2012

\begin{abstract}
As fatty acids (FA) may become included among the quality parameters setting milk prices, their variation during diet changes needs to be investigated. The aim of this work was to study the kinetics of milk FA during rapid or progressive transition from hay- to pasture-based diets. Two farms in the southwestern Alps were selected. The milk of five Valdostana Red Pie cows from each farm was analysed on days $0,1,2,3,5$ and 7 (at day 1, pasture was introduced into the diet), and thereafter twice a week. Changes in the milk FA became significant after days 3 or 5 . The FA from $\mathrm{C} 4: 0$ to $\mathrm{C} 18: 0, \mathrm{C} 18: 2 n-6, \mathrm{C} 18: 3 n-3$ and $\mathrm{C} 20: 0$ became stable after day 5 for both transition types. The cis9-C18:1, trans 10+trans $11-\mathrm{C} 18: 1$ and cis9trans $11-$ conjugated linoleic acid (CLA) became stable 3, 16 and 16 days after the maximum pasture intake, respectively. The C4:0 peaked at 3 days after pasture introduction or increase in the diet, probably reflecting high butyrate production in the rumen due to the high carbohydrate concentration in fresh herbage. The kinetics of all FAs fitted a log-normal cumulate distribution (except for C4:0), but model coefficients did not differ between the rapid and the progressive transition. After diet transition, only cis9C18, cis9trans11-CLA, C18:3n-3, the mono-unsaturated and poly-unsaturated FA, and the sum of CLA isomers increased faster in the rapid transition than in the progressive transition diet (higher $a$ coefficients), because of the higher initial pasture intake. Knowledge of the kinetics of milk FA when pasture is introduced into the diet could help farmers to improve milk nutritional quality.
\end{abstract}

M. Coppa · A. Gorlier · M. Lonati · G. Lombardi

Department AGROSELVITER, University of Turin, Via L. da Vinci 44, 10095 Grugliasco, Italy

M. Coppa $(\bowtie) \cdot$ B. Martin

INRA, UR 1213 Herbivores, 63122 Saint-Genès-Champanelle, France

e-mail: mauro.coppa@unito.it

E. M. Russo

Chemical Laboratory of Turin Chamber of Commerce, Via Ventimiglia 165, 10127 Torino, Italy 


\section{牧草类型对乳脂肪酸动力学的影响}

摘要 : 乳脂肪酸组成是决定乳的价格很重要的质量参数, 乳脂肪酸组成的变化与饲料有直接 的关系。本文目的是考察干草饲料向牧草饲料的快速转变和渐进转变期间乳脂肪酸变化的 动力学。阿尔卑斯山西南部的两个牧场作为研究对象, 在 $0,1,2,3,5,7 \mathrm{~d}$ 分别对来自两个牧场的 5 头Valdostana Red Pie奶牛的乳样进行了分析 (在第 $1 \mathrm{~d}$ 就添加了牧草), 之后一个星期采两次 样品。实验结果表明: 在第 $3 \mathrm{~d}$ 或第 $5 \mathrm{~d}$ 后, 乳脂肪酸组成较之前差异显著; 在第 $5 \mathrm{~d}$ 之后两种不同 饲料类型的奶牛乳脂肪酸 C4:0到 C18:0, C18:2n-6, C18:3n-3 和 C20:0含量趋于稳定。在牧草摄 入量达到最大以后, cis 9 -C18:1, trans $10+$ trans $11-C 18: 1$ 和 $c i s 9$,trans 11-CLA的含量分别在第 $3 \mathrm{~d}, 16 \mathrm{~d}, 16 \mathrm{~d}$ 达到稳定。 $\mathrm{C} 4: 0$ 的含量在添加牧草或增加牧草的摄入量以后的第3 $\mathrm{d}$ 达到最大, 该 结果反映了由于新鲜草料含有较高含量的碳水化合物导致牛的瘤胃里产生较高含量的丁酸 盐。所有的脂肪酸 ( $\mathrm{C} 4: 0$ 除外) 的动力学过程都遵循正态分布, 但是在饲料快速转变和渐进转 变之间模型的校正系数没有改变。只有 $c i s 9-\mathrm{C} 18$, cis 9trans11-CLA, C18:3n-3, 单不饱和脂肪 酸, 多不饱和脂肪酸和共轭亚油酸 (CLA) 异构体的总量在牧草的快速转变期间增加的比牧 草渐进转变期间要快 ( $a$ 系数较高), 出现这种结果主要是由于较高的起始牧草摄入量引起 的。了解牧草饲料对乳脂肪酸的动力学知识有助于提高乳的营养和质量。

Keywords Milk fatty acids $\cdot$ Upland pasture $\cdot$ Diet change $\cdot$ Dairy cow

关键词 乳脂肪酸·丘陵草原·饲料变化·奶牛

\section{Introduction}

With growing consumer interest in the nutritional characteristics of dairy products, the significance of fatty acid (FA) composition of milk and cheese is increasing in dairy science. The impact of FA on human health is well known (Givens 2010). The dairy industry is also interested in milk FA composition because of its effects on cheesemaking technology and on cheese texture and sensory properties (Coppa et al. 2011a, b). As FA may become included among the quality parameters setting milk prices, at least in Europe, producers are starting to apply research-based strategies to improve milk FA profiles. The main channel through which producers can readily manage this is through animal feeding. Introducing forages and, in particular, fresh herbage in bovine diets decreases saturated FA (SFA) in milk and increases polyunsaturated FA (PUFA), in particular cis9trans11-conjugated linoleic acid (CLA) and C18:3n-3, the main $\omega-3$ FA (Chilliard et al. 2007).

Several studies have compared the FA profiles of milk from different diets, but only a few have focused on the kinetics of milk FA during the transition from one diet to another. Elgersma et al. (2004) reported rapid changes in milk fat composition when the diet of cows was switched abruptly from temporary grassland exploitation to a silage (maize and ryegrass)-based diet; the FA profile remained stable for 2 days after the diet change. Similar results were obtained by Biondi et al. (2008) in a study of ewes and by Khanal et al. (2008) in a study of cows after an abrupt diet transition from, respectively, a vetch hay (Vicia sativa) and concentrate ration to a vetch and oat pasture diet, and an abrupt transition from a total mixed ration (TMR) to a perennial ryegrass pasture diet and vice versa. CLA and PUFA concentration changes in milk were studied by Kelly et al. (1998) and by La Terra et al. (2010) on cows transferred gradually from a TMR to pasture feeding in controlled and on farm conditions, respectively; however, FA kinetics were not investigated in these studies. Reference 
data have mainly been obtained by monitoring abrupt diet changes in controlled experimental conditions; little is known concerning ordinary farming conditions in which transitions from a winter diet to full grazing diet are usually gradual and variously managed.

The aim of this work was to assess and describe, by means of statistical models, the kinetics of milk FA in ordinary farming conditions during a rapid and a progressive transition from winter hay- to pasture-based diet.

\section{Materials and methods}

\subsection{Experimental design}

The experiment was conducted during the spring of 2009 in the Orco valley, in the southwestern Alps (Piedmont Region, Italy). Two dairy farms, representative of the upland pasture-based farming system, were selected as they managed transitions from winter feeding to spring grazing either rapidly (farm $\mathrm{R}$, from zero grazing to full grazing in 3 days), or progressively in steps (farm $\mathrm{P}$, from zero grazing to full grazing in 16 days). During a 2-week pre-experimental period, before the beginning of the grazing season, five multiparous Valdostana Red Pie cows were selected in each farm based on homogeneous parity, lactation stage and milk yield (Table 1). Winter rations, mainly based on hay and concentrates, were recorded at each farm and the average animal intake was measured (Table 2). All feeds were sampled: subsamples for gross composition were oven dried at $60^{\circ} \mathrm{C}$ for $48 \mathrm{~h}$, while samples for FA analysis were immediately stored at $-20^{\circ} \mathrm{C}$ until analysed. Feed gross and FA compositions are reported in Table 2. At the end of April, the cows were turned out to pasture and managed under strip grazing, with new paddocks offered twice a day in both farms. Vegetation composition was surveyed in each pasture using a vertical point intercept method (Daget and Poissonet 1969) along $25 \mathrm{~m}$ transects. Pasture botanical composition is reported in Table 3. The average herbage intake was assessed at each milk sampling using the sward cutting method (Smith et al. 2005). Briefly, the day before and after each exploitation, 40 and 80 strips, respectively, measuring $1 \times 0.082 \mathrm{~m}^{2}$ were mown at a height of $4 \mathrm{~cm}$. The difference between the pre- and post-event measurements allowed the phytomass consumed to be assessed. Corresponding to each herbage intake measurement, herbage was sampled for chemical gross composition and FA analysis, similarly to winter feeds. Data are reported in Table 2. Individual milk

Table 1 Characteristics of selected cows and average milk yield and composition in the rapid and progressive transition cows during the pre-experimental period

\begin{tabular}{|c|c|c|c|}
\hline Item & $\begin{array}{l}\text { Rapid } \\
\text { transition }\end{array}$ & $\begin{array}{l}\text { Progressive } \\
\text { transition }\end{array}$ & SEM \\
\hline Parity & 4.8 & 3.8 & 0.50 \\
\hline Lactation stage (months) & 4.4 & 4.0 & 0.46 \\
\hline Milk yield $\left(\mathrm{L} \cdot \mathrm{cow}^{-1} \cdot\right.$ day $\left.^{-1}\right)$ & 13.3 & 13.4 & 1.00 \\
\hline Milk fat content $\left(\mathrm{g} \cdot \mathrm{kg}^{-1}\right)$ & 30.7 & 35.0 & 1.57 \\
\hline Milk protein content $\left(\mathrm{g} \cdot \mathrm{kg}^{-1}\right)$ & 28.5 & 33.1 & 1.22 \\
\hline
\end{tabular}




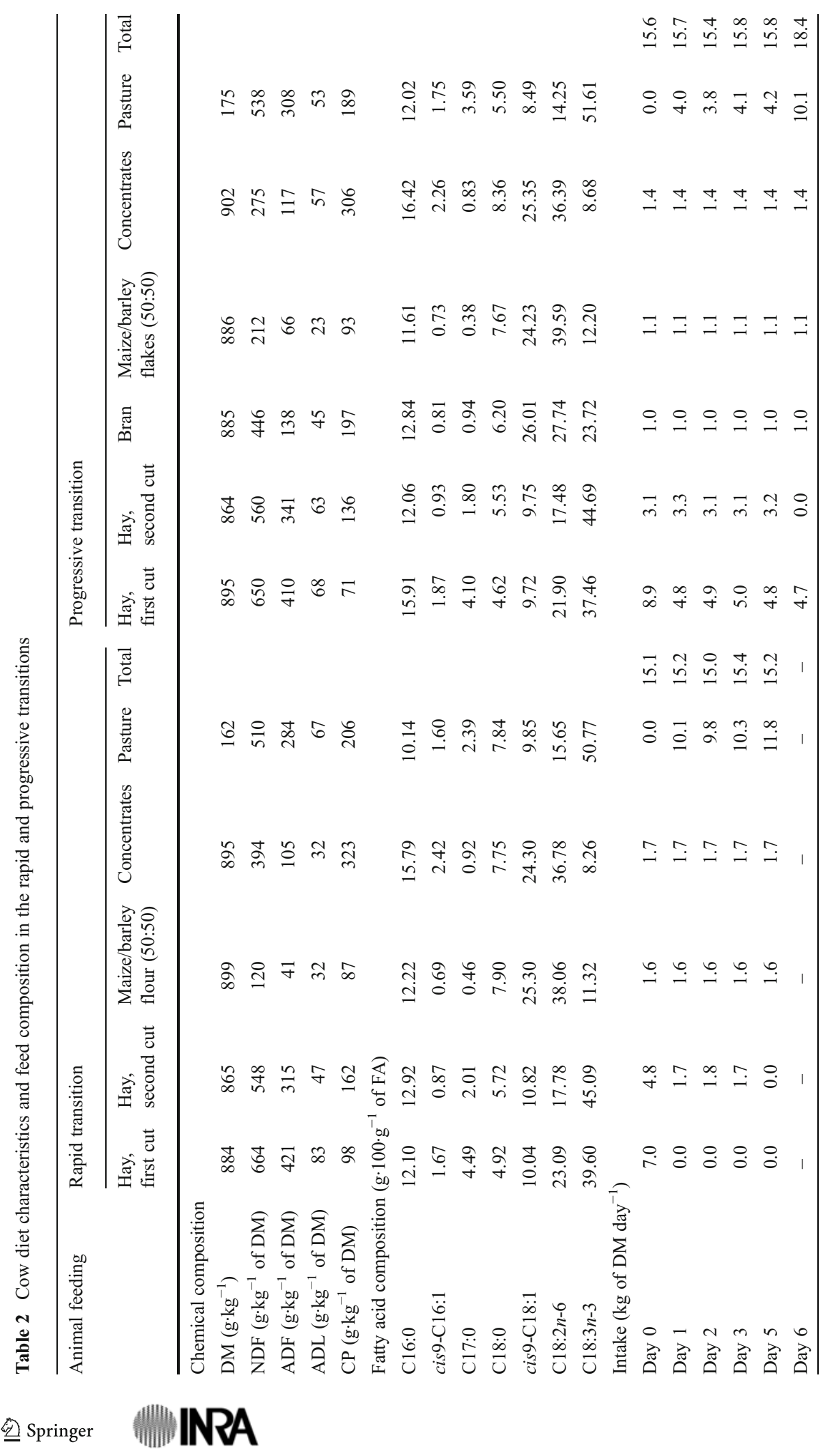




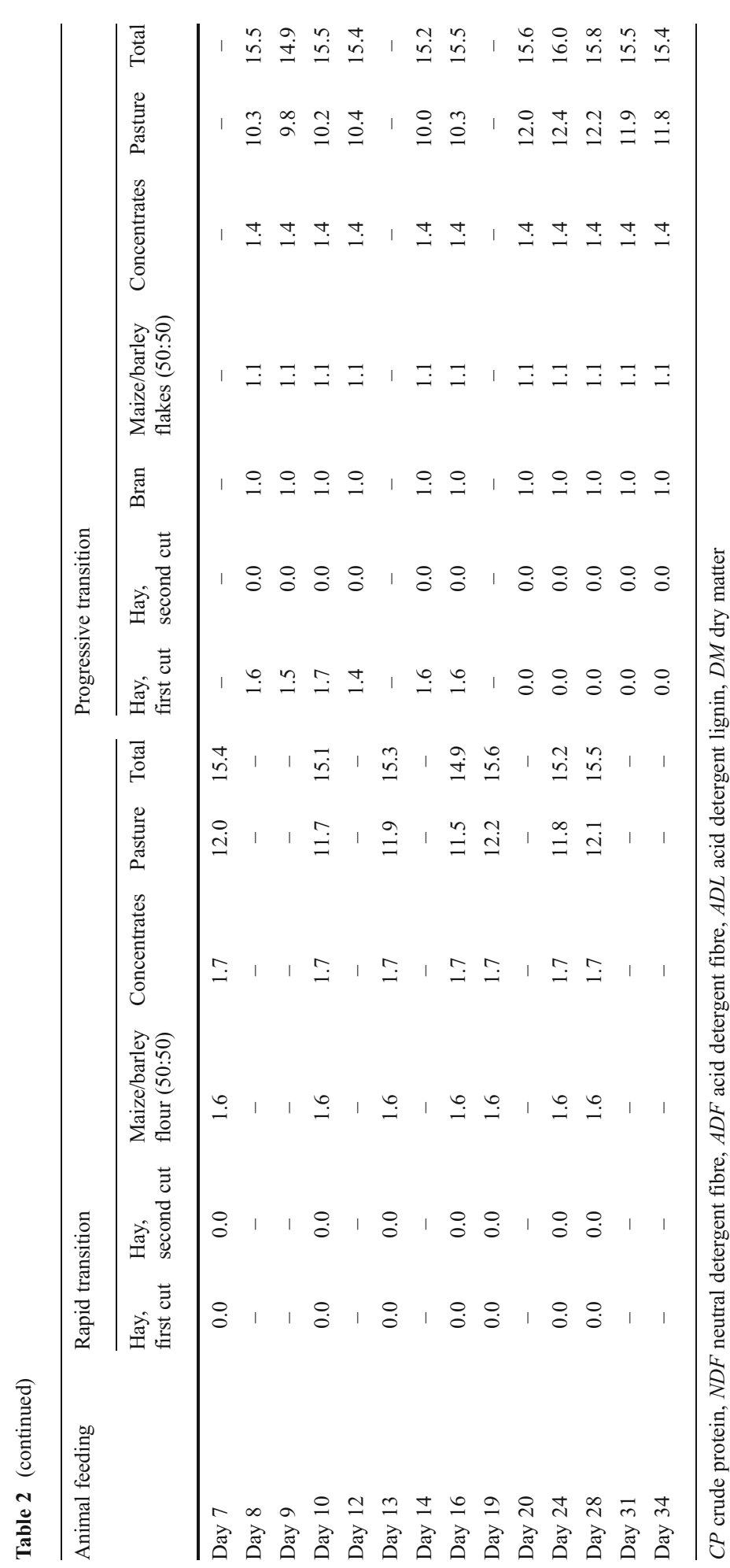


Table 3 Botanical composition of the upland pasture exploited by the rapid and progressive transition cows during the experiment ( $S C$ specific contribution)

\begin{tabular}{lcllc}
\hline Rapid transition & & & Progressive transition \\
\cline { 5 - 5 } Species & SC (\%) & & Species & SC (\%) \\
\hline Dactylis glomerata & 9.0 & & Dactylis glomerata & 9.0 \\
Achillea gr. millefolium & 8.8 & & Achillea gr. millefolium & 7.7 \\
Polygonum bistorta & 8.6 & & Festuca pratensis & 6.8 \\
Poa pratensis & 7.8 & & Trifolium repens & 6.7 \\
Festuca pratensis & 6.8 & & Taraxacum officinale & 6.0 \\
Taraxacum officinale & 5.6 & & Polygonum bistorta & 5.2 \\
Ranunculus acris & 4.2 & & Festuca nigrescens & 5.2 \\
Trifolium repens & 4.0 & & Ranunculus acris & 3.7 \\
Anthriscus sylvestris & 2.8 & Lolium perenne & 3.5 \\
Festuca nigrescens & 2.6 & Poa pratensis & 3.5 \\
Number of species & 59 & Number of species & 68 \\
\hline
\end{tabular}

samples from morning milking were collected for milk gross composition (fat, protein, lactose, urea and somatic cell count) and FA analysis (1) three times during the pre-experimental period, (2) on days 1, 2, 3, 5 and 7 starting from the morning after the beginning of the grazing season (in farm $\mathrm{P}$, the sequence was restarted at each herbage increase in the cow diet), and (3) twice a week thereafter. A 28- and a 34-day period were monitored for farms R and P, respectively. Milk samples were immediately stored at $-20^{\circ} \mathrm{C}$ until analysed. At each milk sampling, daily individual milk yield was also measured.

\subsection{Analysis}

\subsubsection{Animal feeding}

Feed samples for gross chemical composition were ground in a Cyclotec mill (Foss Tecator, Hoganas, Sweden), sieved through a 1-mm screen, and analysed for crude protein (ASPA 1982), neutral detergent fibre, acid detergent fibre and acid detergent lignin (AOAC 1990). Feed FA analyses were performed by forage fat fraction extraction (gram per kilogram of dry matter content) with petroleum ether (Soxtec System HT.6 Extraction Unit and Service Unit; Foss Tecator, Hoganas, Sweden) according to the method reported in Thiex et al. (2003). After extraction, the forage fat fraction was analysed by gas chromatography (GC) as described below for milk.

\subsubsection{Milk}

Fat and protein contents were measured by infrared spectrophotometry (MilkoScanFT 6000, Foss System, Hillerød, Denmark). Extraction and quantification 
of FA from milk were performed using methods ISO 5508:1990 (ISO 1990) and EN ISO 5509:2000 (ISO 2000). Milk samples were thawed and after addition of ammonia, mixed with $4 \mathrm{~mL}$ of isooctane. Glycerides were transesterified to their corresponding FA methyl esters (FAME) with a solution of potassium hydroxide in methanol $\left(2 \mathrm{~mol} \mathrm{~L}^{-1}\right)$. After centrifugation (3,000 rpm for $\left.10 \mathrm{~min}\right)$, FA were separated by GC with an SP-2330 fused silica capillary column $(60 \mathrm{~m} \times 0.25 \mathrm{~mm}, 0.2 \mu \mathrm{m}$; Supelco, Bellefonte, PA, USA) on an Agilent 7890A (Agilent, Santa Clara, CA, USA) gas chromatograph equipped with an autosampler and a flame ionisation detector. The oven temperature was set to $70{ }^{\circ} \mathrm{C}$, increased to $170{ }^{\circ} \mathrm{C}$ at $15{ }^{\circ} \mathrm{C} \mathrm{min}-1$ and then to $220{ }^{\circ} \mathrm{C}$ at $3{ }^{\circ} \mathrm{C} \mathrm{min}^{-1}$ and held for $15 \mathrm{~min}$. Inlet and detector temperatures were $250{ }^{\circ} \mathrm{C}$. Hydrogen was used as the carrier gas. Quantification was carried out using reference standards (Supelco 37 component FAME mix; LarodanABc9t11-CLA) and the results expressed in absolute values of $g$ FAME per $100 \mathrm{~g}$ FA.

\subsection{Statistics}

Statistical analyses were performed using the SPSS for Windows software package (version 16.0; SPSS Inc., Chicago, IL, USA). The cow was taken as the statistical unit. Milk composition data were processed using the repeated measure model of analysis of variance, where sampling day was the repeated factor. As no significant differences were found for any of the parameters among samples collected on different days during the pre-experimental period, values per cow were averaged and labelled 'day 0'. FA kinetics were modelled by averaging the FA concentrations by date and fitting multiple curves using the $\mathrm{R}$ for Windows software package (R Development Core Team 2010). Among the models proposed by the multiple curve fit, the one with the highest $R^{2}$ adjusted within a group of FA deriving from the same metabolic pathways was selected. The selected model fit was then used on individual milk FA data to obtain the model parameters and their statistics.

\section{Results}

\subsection{Milk composition and FA profile}

Milk yield, fat and protein content did not change during the diet transitions in either farms R or P. A wide variability in the milk FA profiles among cows was observed, regardless of the type of diet transition. However, similar patterns in the kinetics of all FA were observed in all cows (Fig. 1). Figure 2 shows the kinetics of the main FA of milk from the rapid and progressive diet transitions. No differences were observed between days 0 and 2 for any FA in either the rapid or the progressive diet transition milks. Changes in the milk FA profile from day 0 became perceptible after day 2, but they became significant only after days 3 or 5 . A decreasing trend was observed for FA between C4:0 and C17:0, while FA from C18:0 to C20:0 increased with time in both transition types. The sum of SFA, the $n-6 /$ $n-3$ ratio, and the atherogenicity and thrombogenicity indices (Ulbricht and Southgate 1991) decreased with time in both rapid and progressive transitions. By contrast, 

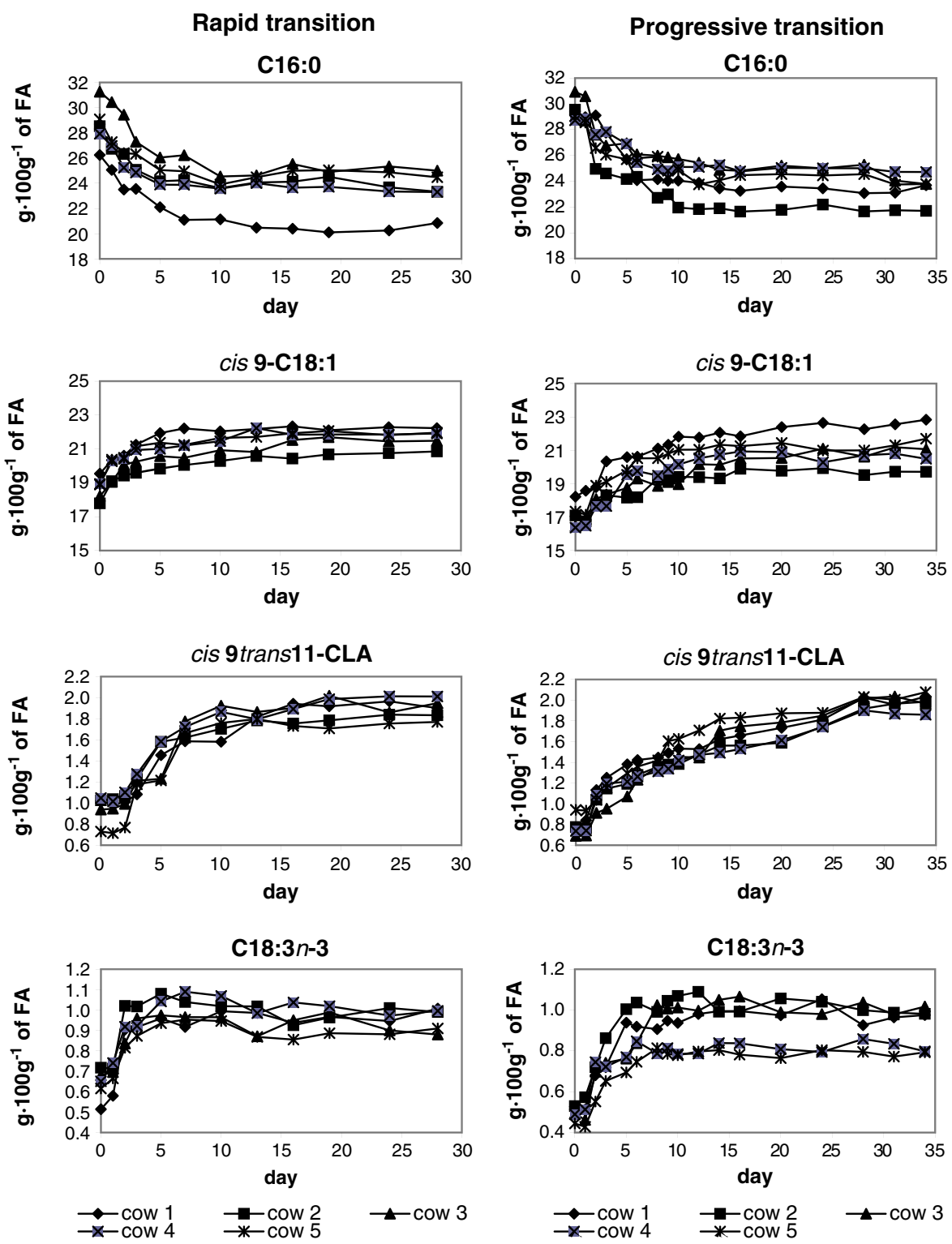

Fig. 1 Individual variations in milk fatty acid concentration during a rapid and a progressive transition from hay- to pasture-based diet

the sum of mono-unsaturated FA (MUFA), and PUFA, the sum of trans-, $n-3$, and $n-6 \mathrm{FA}$, and the cis $9-\mathrm{C} 18: 1 / \mathrm{C} 16: 0$ ratio increased. The FA from C4:0 to C18:0, C18:2n-6, C18:3n-3, and C20:0 became stable after day 5 in both transition types with concentrations not different from those of any of the subsequent sampling days. cis9-C18:1 became stable 3 days after the maximum fresh herbage intake was reached (at days 3 and 10 in the rapid and progressive transitions, respectively), while trans $10+$ trans 11-C18:1 and cis9trans11-CLA became stable after 16 days (at day 16 
in the rapid transition and at day 24 in the progressive one). The SFA became stable after day 6 in milk from both transition types, whereas MUFA, PUFA, and the sum of trans- FA became stable after days 7 and 16 in milk from farms R and P, respectively. Regardless of the transition type, the sum of $n-3$ FA became stable after day 3 , and the sum of $n-6$ FA after day 7. The $n-6 / n-3$ ratio became stable at day 6 in the progressive transition milk, but at day 3 in the rapid transition one. The cis9-
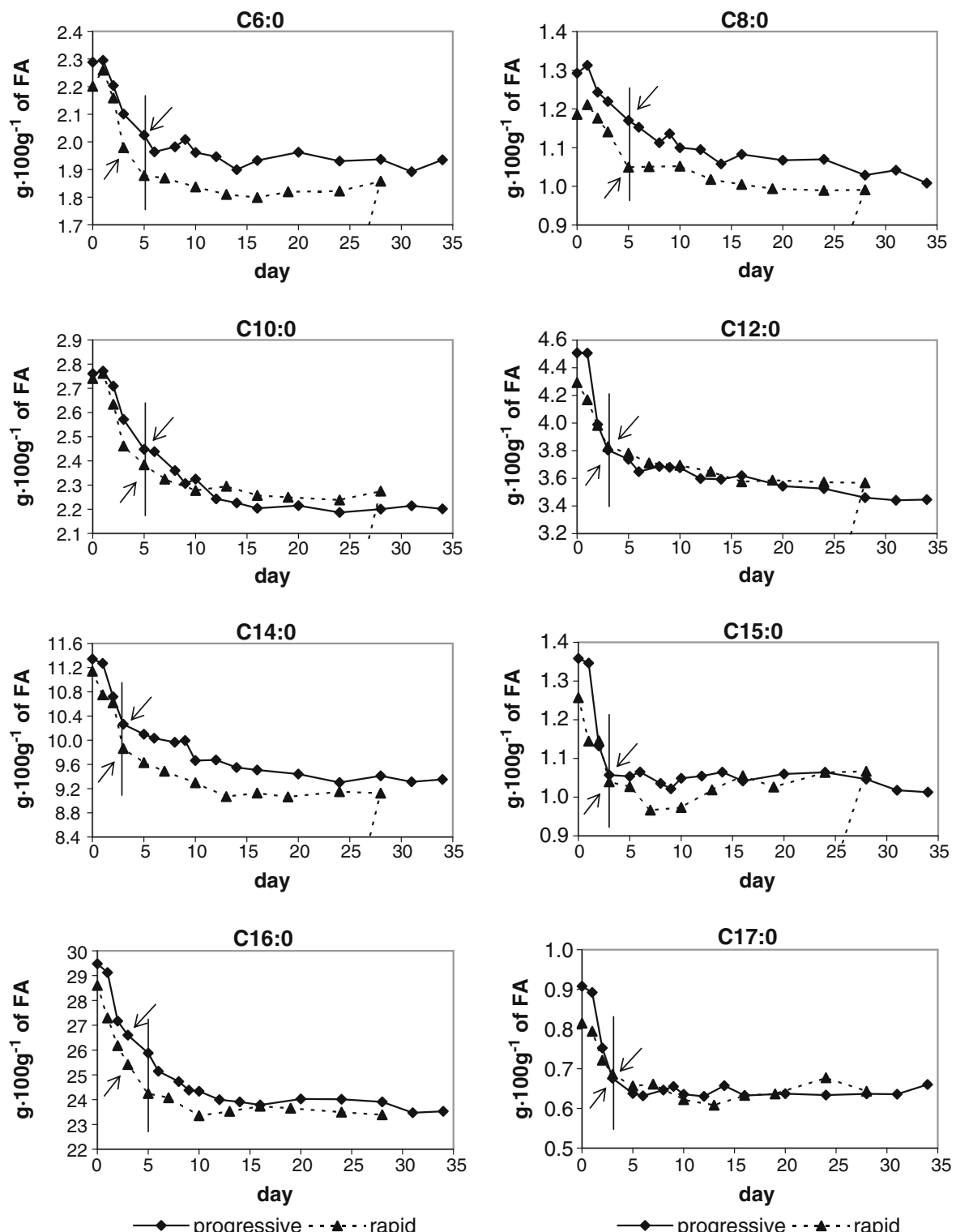

Fig. 2 Kinetics of the main milk fatty acids during rapid and progressive transition from hay- to pasturebased diet. Arrows the day at which differences form winter diet became significant $(P<0.05)$; vertical lines the day after which FA concentrations became stable 

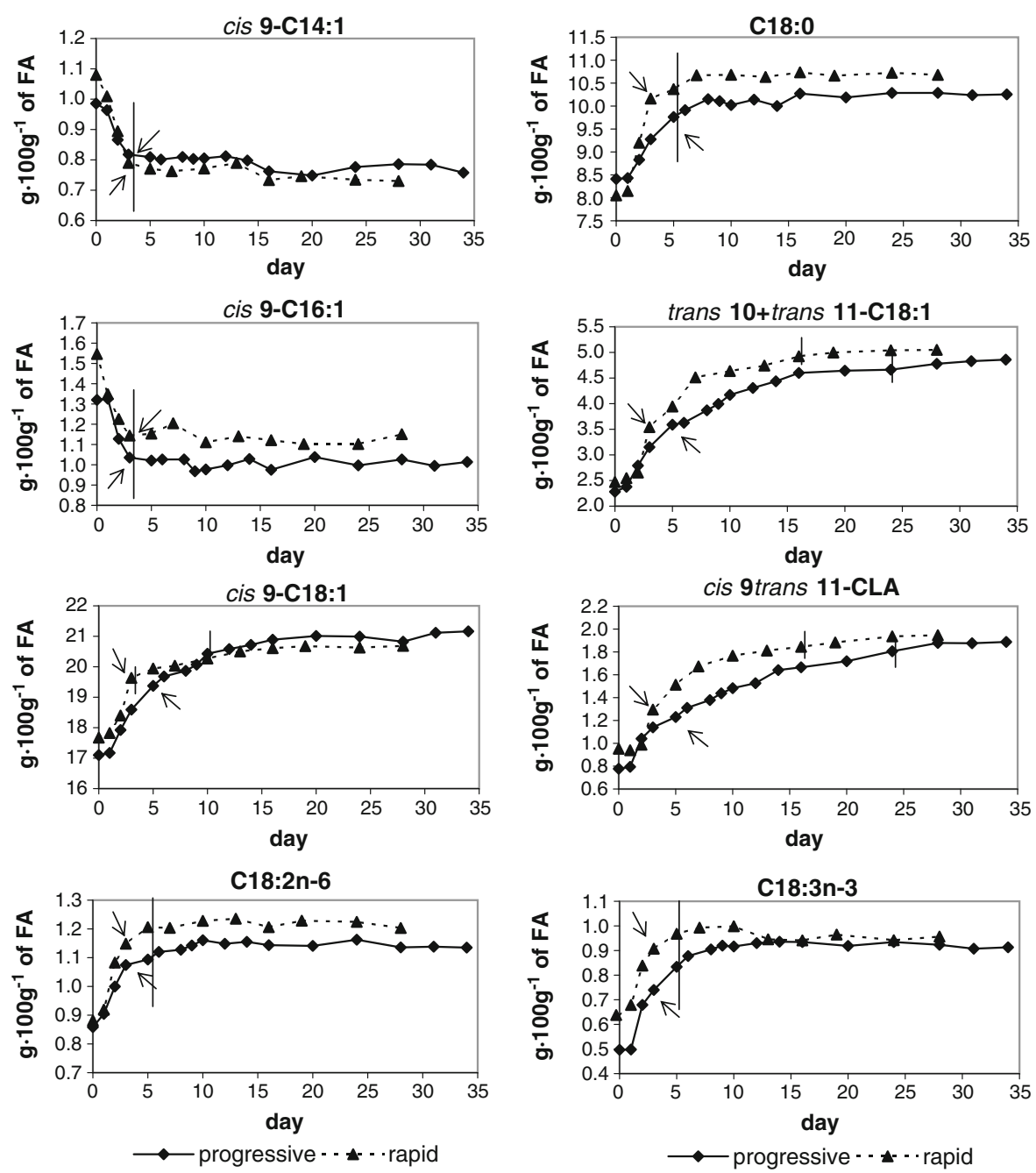

Fig. 2 (continued)

C18:1/C16:0 ratio became stable after day 9 in milk from the progressive transition, but after day 5 in the rapid one. The atherogenicity and thrombogenicity indices were stable after day 7 in milk from the rapid transition, and after days 10 and 16, respectively, in milk from the progressive one.

The C4:0 showed a different trend from all the other FA (Fig. 3). In farm R, the $\mathrm{C} 4: 0$ concentration increased rapidly in milk after the introduction of fresh herbage in the diet, peaking at day 3 . It then decreased to values lower than day 0 at day 16 , after which it remained stable. In farm $\mathrm{P}$, the concentration of $\mathrm{C} 4: 0$ increased rapidly until day 3 . It then decreased similarly to the rapid-transition milk. However, the C4:0 concentration increased again at days 10 and 24, 3 days after each herbage increased in the cow diet. Between days 10 and 24, it decreased; and after day 24, it remained stable. 


\subsection{Kinetic models of milk FA}

Except for C4:0, the kinetics of all the FA were fitted by a log-normal cumulate distribution described by the equation

$$
y=a+0.5 b(\operatorname{erfc}(-\ln (x / c) / 20.5 d)),
$$

where $y$ is the FA concentration, $x$ is the day after the first diet change, $a$ is the intercept on the $x$ axis, $b$ is the slope of the steepest part of the curve, $c$ is the intercept on the $y$ axis, $d$ is the slope of the shallowest part of the curve, and erfc is calculated from

$$
\operatorname{erf} c(x)=1-\operatorname{erf}(x)
$$

and

$$
\operatorname{erf}(x)=(2 / \sqrt{\pi}) \int_{x}^{\infty} e^{-x^{2}} \mathrm{dx} .
$$

The coefficients of the FA equations and their confidence intervals for both transitions are given in Table 4. For almost all FA, all the coefficients of the rapid transition model were included in the confidence interval of the progressive transition model, and vice versa. Hence, no significant differences between the rapid and progressive transition models were found. Only the $a$ coefficients of cis9-C18:1, cis9trans11-CLA, C18:3n-3, MUFA, PUFA and the sum of CLA isomers showed significant differences between transition types, being higher in the rapid than in the progressive transition $(+1.66,+0.17,+0.15,+1.54,+0.52$, and +0.22 , respectively).

Unlike the other FA, C4:0 was not fitted by a model based on day as the independent variable $(x)$. The $\mathrm{C} 4: 0$ peaked 3 days after the introduction or the increase of fresh herbage in the cows' diet, and then promptly decreased. Thus,

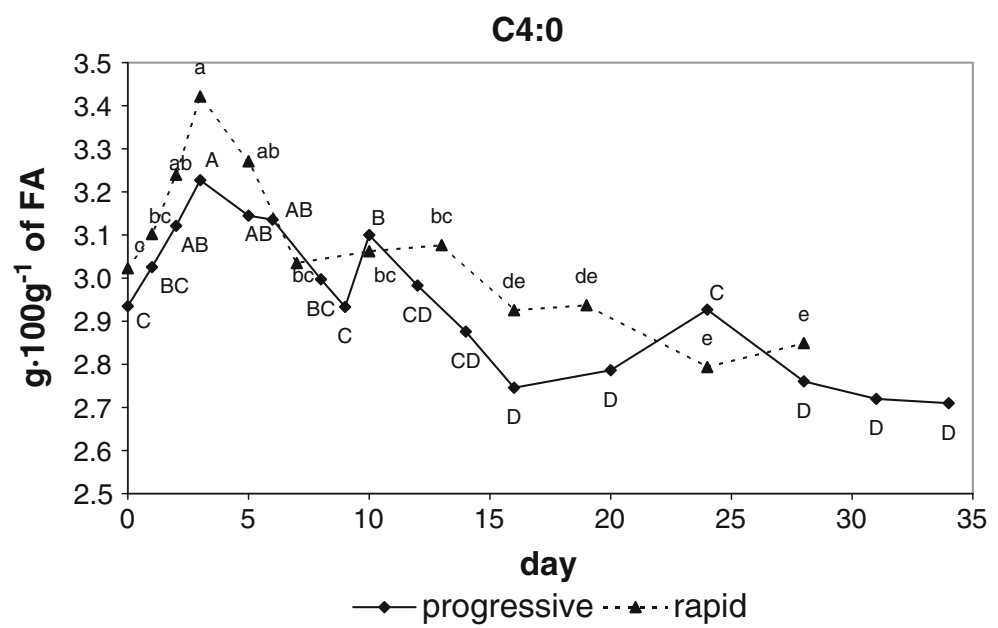

Fig. 3 Kinetics of C4:0 during a rapid and a progressive transition from hay- to pasture-based diet. $a-e$ Differ at $P<0.05$ for the rapid transition $(R)$. $A-D$ Differ at $P<0.05$ for the progressive transition $(R)$ 


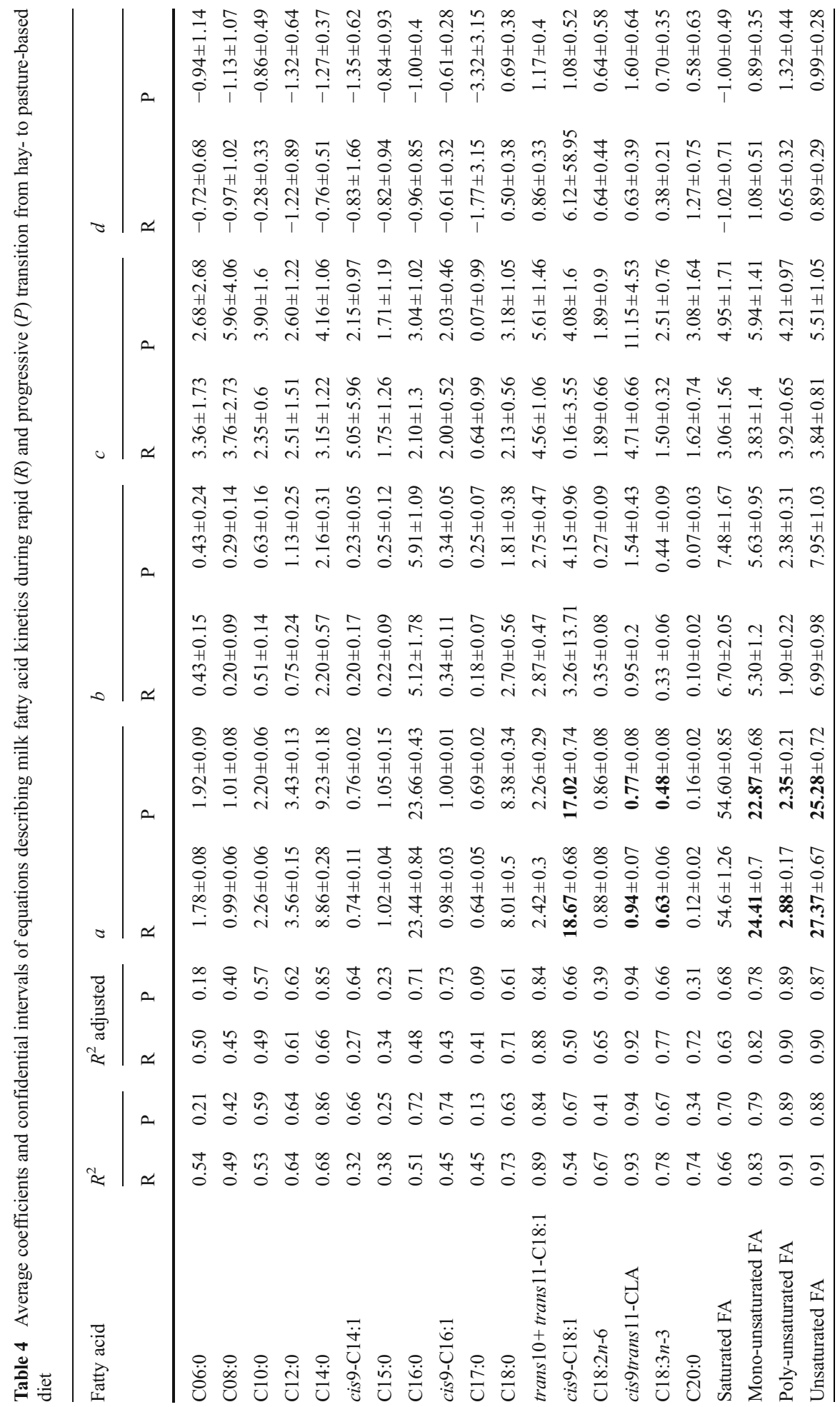




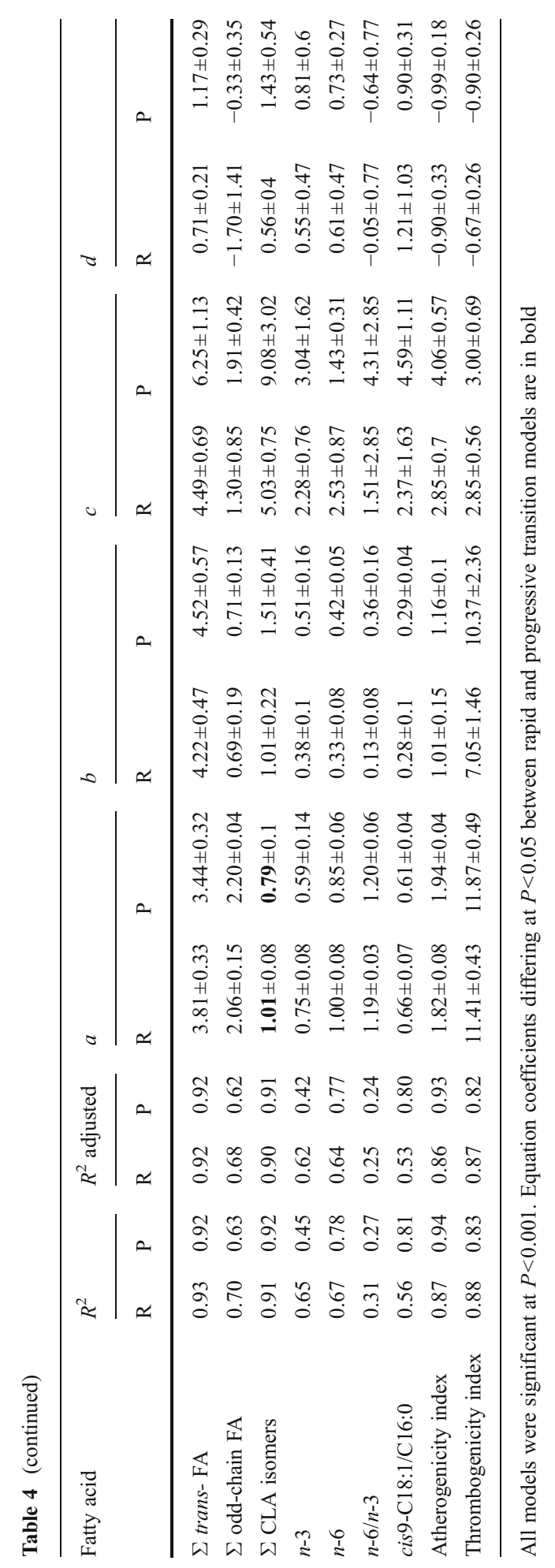


sampling days 3-5 ( $x$ values) were included in each peak, which were not sufficient to give reliable curve parameters.

\section{Discussion}

The changes occurring in the milk FA profile when cows were turned out to upland pastures after a winter hay-based diet has never been studied before in ordinary farming conditions. The decrease in SFA and increase in MUFA and PUFA observed in both rapid and progressive transition milks are in line with reference data obtained in controlled conditions (Kelly et al. 1998; Khanal et al. 2008). Since changes did not occur in the daily concentrate supplementation, the changes in the milk FA profile during transition from hay to pasture could be related to the higher PUFA content in fresh grass (Elgersma et al. 2006) in comparison to hay. A high PUFA concentration in the rumen inhibits the biohydrogenation activity of ruminal bacteria, with consequently more transfer of PUFA to milk (Chilliard et al. 2007). A higher concentration of PUFA in the mammary gland can also inhibit the de novo synthesis of short- and medium-chain SFA (Chilliard et al. 2007). The higher C18:2n-6 concentration in the pasture milk than in the hay milk even though hay had a higher $C 18: 2 n-6$ concentration could be due to the inhibitory effect of ruminal bio-hydrogenation by plant secondary metabolites, abundant in upland pastures (Leiber et al. 2005). The rapid response of milk FA observed at diet changes in ordinary conditions is consistent with results from controlled trials. The 2-day delay before detectable variations in milk FA profile was also observed by Elgersma et al. (2004) for cows switched from pasture to TMR ration, and by Biondi et al. (2008) for ewes after abrupt diet changes. After these variations, the profiles of FA were immediately stable. However, in this study, the differences between the winter hay and the pasture milk became significant only after 3-5 days, and the FA concentrations also became stable later, probably because of the more gradual diet change in both transitions.

The concentrations of trans10+trans11-C18:1 and cis9trans11-CLA increased progressively for both rapid and progressive transition after diet change, becoming stable 2 weeks later than the herbage intake peak. The prolonged increase in vaccenic and rumenic acids and their later stabilisation that we observed in ordinary farming conditions are consistent with the findings of Khanal et al. (2008) for cows that had just starting grazing and by Roy et al. (2006) for cows fed on hay and supplemented with linseed oil in a controlled trial. These authors explained this prolonged increase as the result of a high stability of the rumen environment in forage-rich diets, which may account for a lack of increase in the milk fat of trans10-C18:1, replacing trans11-C18:1, as the predominant trans-C18:1 isomers leaving the rumen. However, such a hypothesis could not be confirmed in our study because trans10-C18:1 and trans11-C18:1 were not separated by GC analysis. Also, cis9-C18:1 showed a prolonged increase, but shorter than that of vaccenic and rumenic acids, becoming stable 3 days after the herbage intake peak. This pattern could be due to the rumen bio-hydrogenation pathway common to vaccenic and rumenic acids, deriving oleic acid at least partially from the mammary desaturation of C18:0, the final result of rumen $\mathrm{C} 18: 2 n-6$ and $\mathrm{C} 18: 3 n-3$ ruminal bio-hydrogenation (Chilliard et al. 2007). 
A novel finding of this study is the kinetics observed for C4:0. The concentration of this FA increased in milk fat at each herbage increase in the diet: the greater the herbage increases, the greater the FA increases. Milk C4:0 can result from different sources, such as the acetyl-coenzyme-A carboxylase pathways and the malonylcoenzyme-A carboxylase pathways, but about $50 \%$ of $\mathrm{C} 4: 0$ in milk may result from acetate and $\beta$-hydroxybutyrate by de novo synthesis in the mammary gland (Jensen 2002; Palmquist et al. 1993). These precursors arise from the microbial fermentation of cellulose, hemicelluloses, and readily degradable carbohydrates in the rumen (Mansbridge and Bòake 1997). Fresh herbage contains a higher amount of readily degradable carbohydrates in comparison to hay, especially when grazed at early phenological stages. Owing to high substrate availability, rumen bacteria responsible for readily degradable carbohydrate degradation may increase rapidly, resulting in an increased $\beta$-hydroxybutyrate production and transfer to the mammary gland, which could explain the peak of $\mathrm{C} 4: 0$ observed in our study. The $\beta$-hydroxybutyrate peak may have been rapidly reduced by the restored equilibrium of the ruminal environment. Similar peaks in ruminal $\beta$-hydroxybutyrate production have already been observed by Lettat et al. (2010) in sheep, corresponding to an abrupt diet change from a hay-based diet to a readily fermentable concentrate-based one.

The kinetics of milk FA profile at turning out to pasture from a hay-based diet had never been studied before using a modelistic approach. The same log-normal cumulate distribution function type was able to fit all FA (except C4:0), for both rapid and progressive transitions. The higher $a$ coefficients for cis9-C18:1, cis9trans11-CLA, C18:3n-3, MUFA, PUFA, and the sum of CLA isomers in the rapid transition than in the progressive transition indicate a more rapid increase in the concentrations of these FA at the beginning of the transition. These differences could mainly be related to the higher amount of herbage in the rapid transition cow diet than in the progressive one, the herbage botanical and chemical composition being quite similar between farms. Some differences in cow characteristics (i.e. parity, lactation stage or milk yield) between farms, difficult to standardise in non-controlled conditions, could have influenced milk FA kinetics. However, it is well known that animal-related factors have a negligible effect on milk FA compared to cow feed (Palmquist et al. 1993).

By contrast, comparing confidence intervals of all coefficients of all the other FA equations, no differences were found between the rapid and the progressive transition milk models for almost all the FA, possibly owing to the broad variability observed among cows. All the cows showed similar trends in milk FA kinetics, but with different FA concentrations before and after diet change. The individual variability was broader when cows were grazing than when they were fed with hay and concentrates, confirming literature data (Kelly et al. 1998; Khanal et al. 2008). Differences in cow fresh herbage intake and in cow grazing selection of plant species, or plant parts richer or poorer in PUFA may explain the broader variability of the milk FA profile of pasture-fed cows (Coppa et al. 2011b; Khanal et al. 2008), especially on highly biodiverse upland pastures.

\section{Conclusion}

Original results obtained in ordinary farming conditions show the kinetics of milk FA profiles during a rapid and a progressive transition from winter hay- to pasture-based 
diets. Statistical models describing such kinetics are proposed. Differences in kinetics between the rapid and progressive transitions were found only for cis9-C18:1, cis9trans11-CLA, C18:3n-3, MUFA, PUFA, and the sum of CLA isomers. The rapid transition showed a more rapid increase in these FA, in relation to the higher initial herbage proportion in the cow diet. Given the impending changes in milk price criteria (at least in Europe), with inclusion of FA profile among the quality parameters, knowing how and how rapidly milk FA profiles change when fresh herbage is introduced in the diet could offer farmers a useful tool to manage diet transitions, improve milk nutritional quality and control income.

Acknowledgments This research project was funded by Regione Piemonte (principal investigator Prof. Andrea Cavallero). The authors thank D. Aimonino and G. Pezzetti for making their farms available for the study, D. Sacco (Dept. Agroselviter, University of Turin) for the statistical support, A. Gotta, and S. Giuliano for their help during sampling and the CRA-FLC Lodi which performed the analyses on forages.

\section{References}

Association of Official Analytical Chemists (AOAC) (1990) Official methods of analysis, 15th ed. Washington, USA

Associazione Scientifica Produzioni Animali (ASPA) (1982) Commissione Valutazione Alimenti. Zoot Nutr Anim 8:387-400

Biondi L, Valvo MA, Di Gloria M, Scinardo Tenghi E, Galofaro A, Priolo A (2008) Changes in ewe milk fatty acids following turning out to pasture. Small Rumin Res 75:17-23

Chilliard Y, Glasser F, Ferlay A, Bernard L, Rouel J, Doreau M (2007) Diet, rumen biohydrogenation and nutritional quality of cow and goat milk fat. Eur J Lipid Sci Technol 109:828-855

Coppa M, Ferlay A, Monsallier F, Verdier-Metz I, Pradel P, Didienne R, Farrugia A, Montel MC, Martin B (2011a) Milk fatty acid composition and cheese texture and appearance from cows fed hay or different grazing systems on upland pastures. J Dairy Sci 94:1132-1145

Coppa M, Verdier-Metz I, Ferlay A, Pradel P, Didienne R, Farruggia A, Montel MC, Martin B (2011b) Effect of different grazing systems on upland pastures compared with hay-diet on cheese sensory properties evaluated at different ripening times. Int Dairy J 21:815-822

Daget P, Poissonet J (1969) Analyse phytologique des prairies - applications agronomiques. Centre National de la Recherche Scientifique, Montpellier

R Development Core Team (2010) R: A language and environment for statistical computing. R Foundation for Statistical Computing, Vienna, Austria. ISBN 3-900051-07-0, URL http://www.R-project.org/

Elgersma A, Ellen G, van der Horst H, Boer H, Dekker PR, Tamminga S (2004) Quick changes in milk fat composition from cows after transition from fresh grass to a silage diet. Anim Feed Sci Tech 117:13-27

Elgersma A, Tamminga S, Dijkstra J (2006) Lipids in herbage. In: Elgersma A, Dijkstra J, Tamminga S (eds) Fresh herbage for dairy cattle. Springer, Nederlands, pp 175-194

Givens DI (2010) Milk and meat in our diet: good or bad for health ? Animal 4(12):1941-1952

International Organisation for Standardization (ISO) (1990) Animal and vegetable fats and oils - analysis by gas chromatography of methyl esters of fatty acids, ISO Standards 5508

International Organization for Standardization (ISO) (2000) Animal and vegetable fats and oilspreparation of methyl ester of fatty acids, Clause 5: trans-esterification method, ISO Standards 5509

Jensen RG (2002) The composition of bovine milk lipids: January 1995 to December 2000. J Dairy Sci $85: 295-350$

Kelly ML, Kolver ES, Bauman DE, Van Amburg ME, Muller LD (1998) Effect of intake of pasture on concentration of conjugated linoleic acid in milk of lactating cows. J Dairy Sci 81:1630-1636

Khanal RC, Dhiman TR, Boman RL (2008) Changes in fatty acids composition of milk from lactating dairy cows during transition to and from pasture. Livest Sci 114:164-175

La Terra S, Marino VM, Manent M, Licitra G, Carpino S (2010) Increasing pasture intakes enhances polyunsaturated fatty acids and lipophilic antioxidants in palsma and milk of dairy cows fed total mix ration. Dairy Sci Technol 90:687-698 
Leiber F, Kreuzer M, Nigg D, Wettstein HR, Scheeder MRL (2005) A study on the causes for the elevated $n-3$ fatty acids in cows' milk of Alpine origin. Lipids 40:191-202

Lettat A, Nozière P, Silberberg M, Morgavi DP, Berger C, Martin C (2010) Experimental feed introduction of ruminal lactic, propionic and butyric acidosis in sheep. J Anim Sci 88:3041-3046

Mansbridge RJ, Bòake JS (1997) Nutritional factors affecting the fatty acid composition of bovine milk. Br J Nutr 78(suppl 1):S37-S47

Palmquist DL, Beaulieu AD, Barbano DM (1993) Feed and animal factors influencing milk fat composition. J Dairy Sci 76:1753-1771

Roy A, Ferlay A, Shingfield KJ, Chilliard Y (2006) Examination of the persistency of milk fatty acid composition responses to plant oil in cow given different basal diets, with particular emphasis on transC18-1 fatty acids and isomers of conjugated linoleic acid. Anim Sci 82:479-492

Smith HJ, Taweel HZ, Tas BM, Tamminga S, Elgersma A (2005) Comparison of techniques for estimating herbage intake of grazing dairy cows. J Dairy Sci 88:1827-1836

Thiex NJ, Anderson S, Gildemeister B (2003) Crude fat, hexanes extraction, in feed, cereal grain, and forage (Randall/Soxtec/Submersion Method): Collaborative Study. J AOAC Int 86:899-908

Ulbricht TLV, Southgate DAT (1991) Coronary heart disease: seven dietary factors. Lancet 338:985-992 